\title{
Theca Cell
}

National Cancer Institute

\section{Source}

National Cancer Institute. Theca Cell. NCI Thesaurus. Code C12572.

An endocrine cell located in the ovary that functions to produce androgens for estrogen biosynthesis and provide structural support during oocyte maturation. 